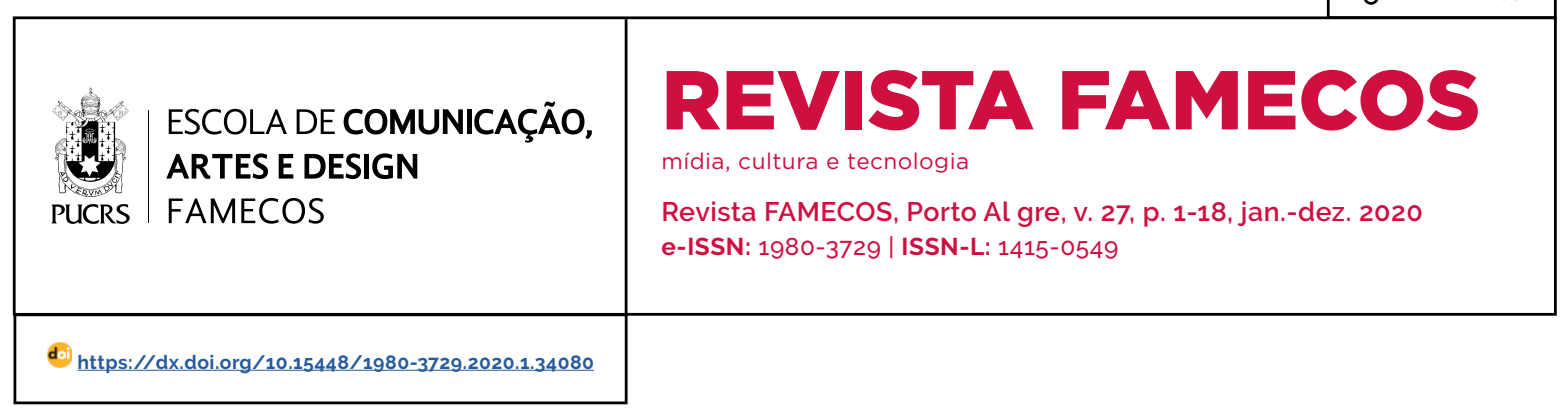

AUDIOVISUAL

\title{
Mario Cravo Neto e a poética da mitologia afro-brasileira
}

\author{
Mario Cravo Neto and the poetry of Afro-Brazilian mythology \\ Mario Cravo Neto y la poesía de la mitología afro-brasileña
}

\section{Rafael Castanheira ${ }^{1}$}

orcid.org/0000-0002-2878-667X

emaildocastanheira@gmail.com

Recebido em: 4 mai. 2019.

Aprovado em: 6 nov. 2019. Publicado em: 17 set. 2020.
RESUMO: Este artigo aborda a atuação de Mario Cravo Neto no processo tanto de transposição das fronteiras que insistiam em separar o documentário fotográfico das artes visuais no Brasil quanto de questionamento dos padrões historicamente instituidos sobre a chamada "fotografia documental". Para isso, analisa o seu livro Laróyè, no qual Cravo Neto, a partir de fotografias de pessoas, animais, cores, objetos e situações registradas nas ruas de Salvador, Bahia, sugere a presença do orixá Exu. Ao ampliar as possibilidades de produção e uso do documento fotográfico a partir de estratégias técnicas, estéticas e conceituais que mais se aproximam daquelas adotadas em projetos de caráter artístico, rompe não com a documentação em si, mas com os seus modelos tradicionais baseados na ideia de fotografia como reprodução fiel da realidade.

Palavras-chave: Fotografia Documental. Mario Cravo Neto. Exu.

ABSTRACT: This article deals with the work of Mario Cravo Neto in his process to break the barriers that used to separate documentary photography from the fields of the visual arts in Brazil and to question traditional pattern of this photographic gender. In this regard, his book Laróye will be analysed in which the author, from pictures of people, animals, colours, objects and situations recorded in Salvador's streets, Bahia, suggest the presence of the orixá Exu. The analysis of this publication showed that when the production possibilities and the use of the photographic document - especially deriving from technical, aesthetic and conceptual strategies that are closer to the ones used in artistic projects - were increased, the photographer ruptured not with the documentation per se, but with its traditional models based in the idea of photography as faithful reproduction of reality.

Keywords: Documentary Photography. Mario Cravo Neto. Exu.

RESUMEN: Este artículo aborda la actuación de Mario Cravo Neto en el proceso tanto de transposición de las fronteras que insistian en separar el documental fotográfico de las artes visuales en Brasil como del cuestionamiento de los patrones históricamente instituidos sobre la llamada "fotografía documental". Para ello, se analiza su libro Laróyè, en el que Cravo Neto, a partir de fotografias de personas, animales, colores, objetos y situaciones registradas en las calles de Salvador, Bahia, sugiere la presencia del orixá Exu. Al ampliar las posibilidades de producción y uso del documento fotográfico a partir de estrategias técnicas, estéticas y conceptuales que más se aproximan a aquellas adoptadas en proyectos de carácter artístico, rompe no con la documentación en sí, sino con sus modelos tradicionales basados en la idea de la fotografia como reproducción fiel de la realidad.

Palabras clave: Fotografía Documental. Mario Cravo Neto. Exu. 


\section{Introdução}

Nas últimas décadas, uma vasta bibliografia acerca das relações entre fotografia e realidade e das fronteiras (cada vez mais fluidas) entre realidade e ficção, entre documento e arte tem mostrado que, ao contrário da crença na sua linguagem "objetiva" e "direta", a fotografia não é o espelho do real. Ou seja, a fotografia "não pode ser o registro puro e simples de uma imanência do objeto" (MACHADO, 1984, p. 40). Tais estudos têm alertado para o fato de que, apesar de trazer o "traço do real" pelo processo de impressão luminosa, indicando assim a existência do referente (DUBOIS, 1994), a fotografia contém em sua gênese, uma grande parte de realidades e ficções em sua trama (KOSSOY, 2002). A fotografia é, na verdade, uma "interrogação do real", a "interrogação sobre a existência, sobre o tempo, sobre a matéria e sobre a imagem" (SOULAGES, 2010, p. 346). Ademais, tais teóricos comprovam, sobretudo, que a fotografia é "pura invenção" (FONTCUBERTA, 2000, p. 165), ela é produto de um aparelho, a câmera, que gera, manipula e armazena simbolos e, por isso, precisa ser decifrada (FLUSSER, 2002). Em suma, essas pesquisas têm mostrado que o fazer fotográfico envolve procedimentos de criação subjetiva do autor, que vai buscar desenvolver os seus trabalhos com base em sua origem, o seu meio, a sua formação, as suas referências visuais, como também nas tecnologias e nas práticas culturais do seu tempo.

Se a chamada "fotografia documental", no sentido mais consagrado desse termo, ancorase na capacidade da fotografia de registrar diretamente a realidade, na sua natureza verossimil e no seu valor de autenticidade, como pensá-la atualmente, quando as noções de objetividade e realismo, assim como a função probatória, a ela atribuidas vêm sendo questionadas não apenas por teóricos, mas também por fotógrafos que, explorando sua carga simbólica, assumem abertamente o caráter polissêmico de suas imagens e narrativas?

Assim, os projetos documentais que visavame ainda visam à representação objetiva do mundo têm sucumbido às necessidades de alguns fotógrafos de partir das suas experiências e visões pessoais para interpretá-lo e construí-lo segundo uma lógica poética que abarque a complexidade dos seus temas - às vezes, abstratos e invisiveis. Trata-se, portanto, de uma mudança de abordagem que vêm apontando para novos conceitos éticos e estéticos da documentação fotográfica na contemporaneidade. Partindo desta perspectiva, podemos nos perguntar sobre este processo de mudança nos trabalhos de fotodocumentação no Brasil.

No Livro Fotografia Brasileira Contemporânea, publicado por ocasião da exposição homônima, realizada em Frankfurt, em 1994, o museólogo e curador Paulo Herkenhoff analisa a história recente da fotografia no Brasil e observa que durante a ditadura de 1964 a cultura no País voltou-se para a formulação de estratégias politicas para fazer frente ao regime militar, como a tática prevalecente da denúncia sutil através do fotojornalismo. Ele observa, porém, que com a lenta distensão política no final da década de 1970 a fotografia começou a se abrir para diferentes formas de expressão, se libertando "daquela tarefa de revolta e defesa da liberdade" (HERKENHOFF, 1994, p. 43).

Essa exposição apresentou três gerações de fotógrafos, cujas imagens, segundo seu curador, "não pretendem ser um retrato do Brasil, mas o recorte de uma atitude" (HERKENHOFF, 1994. p. 43-44). Nela, Herkenhoff aponta Mário Cravo Neto (1947-2009), Claudia Andujar (1931 -) e Miguel Rio Branco (1946 -) como integrantes da primeira geração que, na década de 1970 , mostrou uma "atitude de experimentação que se expande, alcançando seu ponto principal na atualidade" (1994, p. 43-44). Além disso, Herkenhoff ainda afirma que esses fotógrafos "vivem a busca incessante da alteridade, da apreensão desse ser incomensurável, o Outro", ressaltando o fato de que, em uma sociedade complexa como a brasileira, com sua violenta história, sua formação étnica e sua estrutura de classes, a cultura do século XX mantém um traço de busca de identidade nacional contra um passado colonial (HERKENHOFF, 1994, p. 43-44).

Diante desse contexto, o presente artigo 
busca compreender tal atitude pioneira do fotógrafo Mario Cravo Neto, que poderia ser identificada como fundadora de uma nova fase na fotografia brasileira. Afinal, além de explorar novas estratégias estéticas que flexibilizam as fronteiras entre arte e documentação, o seu trabalho marcaria um momento singular na história da fotografia no Brasil em que os sujeitos fotografados - no seu caso, majoritariamente o povo baiano, e mais especificamente a população negra e pobre em suas manifestações populares e religiosas - vivem um processo dialógico de construção de sua identidade.

Como procedimento metodológico, fizemos primeiramente uma revisão bibliográfica que, segundo Prodanov e Freitas (2013), é elaborada a partir de materialjá publicado, constituido principalmente de livros, revistas, publicações em periódicos e artigos científicos. A partir de levantamento e análise de textos não apenas sobre fotografia documental, mas, sobretudo, sobre a biografia de Mario Cravo Neto e os temas abordados em seus trabalhos de fotodocumentação, percebemos que, ao longo de mais de quarenta anos da carreira como artista, ele experimentou o desenho, a pintura, a escultura e mesmo sem passar pelo universo do fotojornalismo e das publicações editoriais de caráter documental - escolheu a imagem fotográfica como o principal meio para se expressar, envolver-se e documentar o povo baiano e as suas manifestações populares e religiosas, tanto no ambiente sagrado das igrejas e terreiros de candomblé, quanto no ambiente profano das ruas, mercados, feiras, praia e fortes de Salvador.

Se os seus primeiros trabalhos autorais realizados no final dos anos 1960 já indicavam a escolha de abordagens fotográficas incomuns para o campo documental, distanciando-os, em parte, dos modelos convencionais praticados até essa época no país, as suas produções mais recentes exploram estratégias que embaralham completamente as fronteiras entre o real e o ficcional, e são por ele abertamente assumidas como uma maneira de combinar experimentação visual com análise e interpretação dos seus temas.

Adepto do candomblé e, portanto, consciente de que mitologia africana e realidade na cidade de Salvador, Bahia, se misturam, Cravo Neto publicou, em 2000, Laróyè. Tanto pelo contexto de transposição das fronteiras que insistiam em separar o documentário fotográfico das artes visuais no Brasil como pelo questionamento dos padrões historicamente instituidos sobre a chamada "fotografia documental", este nos pareceu ser o seu mais emblemático livro, cujas fotografias sugerem a presença de Exu entre os habitantes de Salvador. Buscando símbolos que remetem a esse orixá nos corpos humanos e de animais, em objetos, cores, entre outros elementos dispersos pelas ruas, mercados e praias da capital baiana, o fotógrafo não apenas documentou a cidade, mas, principalmente, interpretou, a partir dela, a origem e a relação ancestral mítica de Exu com a sociedade soteropolitana.

Desse modo, ao focarmos em uma obra específica de um artista, adotamos ainda neste artigo o método de Estudo de Caso que, como explica Fachin (2001, p. 42) "consiste no estudo profundo e exaustivo de um ou poucos objetos, de maneira que permita seu amplo e detalhado conhecimento", sendo "caracterizado por ser um estudo intensivo". Ainda sobre este tipo de estudo, Fonseca (2002, p. 33) destaca sua "forte tendência descritiva" e afirma que o mesmo pode decorrer de acordo com uma "perspectiva interpretativa, que procura compreender como é o mundo do ponto de vista dos participantes, ou uma perspectiva pragmática, que visa simplesmente apresentar uma perspectiva global, tanto quanto possivel completa e coerente, do objeto de estudo do ponto de vista do investigador".

Assim, descreveremos e analisaremos a seguir parte das fotografias de Laróyè, no qual, além de efeitos visuais, Cravo Neto adere a estratégias ficcionais de encenação e, sobretudo, de ressignificação simbólica dos corpos de pessoas e animais e também de objetos registrados nas ruas de Salvador a fim de afirmar a ancestral carga espiritual presente no homem baiano e no ambiente que o rodeia e, mediante ela, sugerir a presença, em Salvador, de Exu, um dos mais complexos orixás do panteão dos deuses iorubanos. 


\section{Laróyè: uma documentação poética sobre Exu}

Publicado, em 2000, pela editora do próprio autor, a Áries, Laróyè possui capa em acetato transparente com o título grafado em dourado (Figura 1), revestindo uma das 141 fotografias do livro que, em seu formato retangular ( $24 \times 35.5$ $\mathrm{cm}$ ), apresenta-as sempre na horizontal e sem as tradicionais margens brancas, ou seja, são impressas sempre "sangradas" nas suas páginas. A obra é fruto do trabalho fotográfico de mais de vinte anos de Cravo Neto, realizado entre 1977 e 1999, em suas deambulações pelas ruas, praias, mercados, fortes e igrejas de Salvador.

Figura 1 - Capa do livro Laróyè

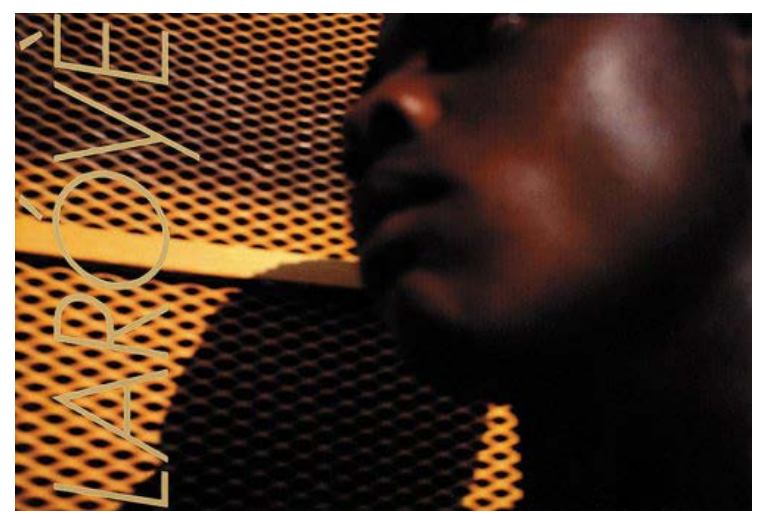

Fonte: Cravo Neto, 2000.

As fotografias de Laróyè não são acompanhas por legendas. Contudo, há nas páginas que as antecedem diversas informações textuais: depois de um pequeno texto de agradecimento do autor, vemos uma dedicatória "a Ėșù Maragbó" e duas epigrafes, sendo a primeira com a frase escrita em iorubá "Sonso abé kó lóri erü", que significa "A lâmina (sobre a cabeça) é afiada, ele não tem (pois) cabeça para carregar fardos", ${ }^{2}$ e a segunda epigrafe "Ėșù é o companheiro oculto das pessoas". Dessa forma, com base nessas duas epigrafes e no próprio título da obra, já podemos identificar a reverência do autor para com Exu: "Laróyè" é uma saudação em iorubá que evoca a presença e os poderes desse orixá. E, finalmente, nas páginas seguintes, a temática é revelada, tanto no texto de abertura redigido pelo escritor, crítico de arte e amigo de Cravo Neto, Edward Leffingwell, quanto no poema "Exu", escrito pelo pai do fotógrafo, Mario Cravo Júnior, e disposto ao final do livro.

Após apresentar brevemente o contexto sóciohistórico da cidade de Salvador, Leffingwell destaca Exu como o mais humano dos orixás e, de acordo com o mito da criação iorubá, conta a história do nascimento desses deuses:

\begin{abstract}
No início, conta a história, Yemoja e seu irmão Aganju, que representa o agreste, tiveram um filho, chamado Orúngan, a região do ar e do espaço situada entre o céu e a terra. Mais tarde Orúngan enamorou-se de sua mãe, Yemoja, e, aproveitando-se da ausência do pai, a possuiu. Logo após o ato, Yemoja fugiu, torcendo as mãos, lamentando-se, mas logo foi perseguida por seu filho, que tentava consolá-la. Como não podia viver sem ela, Orúngan, propôs que se unissem nas sombras, tornando-se assim seu marido secreto. Yemoja o repeliu fugindo e, quando Orúngan estendeu-lhe a mão para capturá-la, ela caiu de costas no chão. Seu corpo se inchou, de seus seios brotaram dois cursos d'água, que se encontraram formando um lago, e de seu ventre aberto sairam os òrisà, que governam as direções do mundo. $O$ primeiro deles foi Ėsù. Não é de admirar que seja o "travesso" (LEFFINGWELL, 2000)
\end{abstract}

Com base na mitologia dos orixás, Leffingwell escreve sobre a relação entre as fotografias de Mario Cravo Neto com a simbologia de Exu, destacando algumas das suas características a fim de permitir ao leitor uma melhor interpretação do conteúdo de Laróyè. Afinal, "este livro começa e termina com Ėsù", explica o escritor, ao salientar ainda que esse orixá (força pura, axé imaterial) encontrar-se-ia materializado nas cenas registradas pelo olhar atento do fotógrafo: "Mario Cravo reconhece o orixá entre nós, porque é ele quem olha" (LEFFINGWELL, 2000).

Desse modo, além da observância às suas questões formais, a interpretação das fotografias de Laróyè demanda o conhecimento do espectador acerca dos diversos e paradoxais aspectos que definem Exu, uma das figuras mais complexas do panteão dos orixás. Muitos desses aspectos são narrados nas histórias da mitologia

\footnotetext{
2 A tradução desta frase do iorubá para o português foi obtida no livro de Pierre Verger Orixás: deuses iorubás na África e no Novo Mundo (VERGER, 2002, p. 78)
} 
dos deuses iorubanos. Daí a importância de partirmos desses mitos para interpretá-las, o que pode ser notado logo na primeira imagem do livro (Figura 2). Nela, observamos um homem negro curvado, como se ele estivesse saindo das águas do mar que batem na altura de suas canelas. Registrado a partir de um ângulo que não nos permite enxergar a sua cintura, o personagem parece estar nu e tem os seus olhos fechados, sugerindo o seu nascimento, a sua chegada de maneira natural ao mundo. Assim, com base no mito transcrito acima por Leffingwell, é possivel associarmos o personagem da foto de Mario Cravo Neto a Exu, já que este e também os seus irmãos orixás, segundo a mitologia da criação iorubá, teriam nascido das águas que surgiram no local de queda e morte de sua mãe, lemanjá.

Figura 2 - Mario Cravo Neto. Fotografia do Livro Laróyè

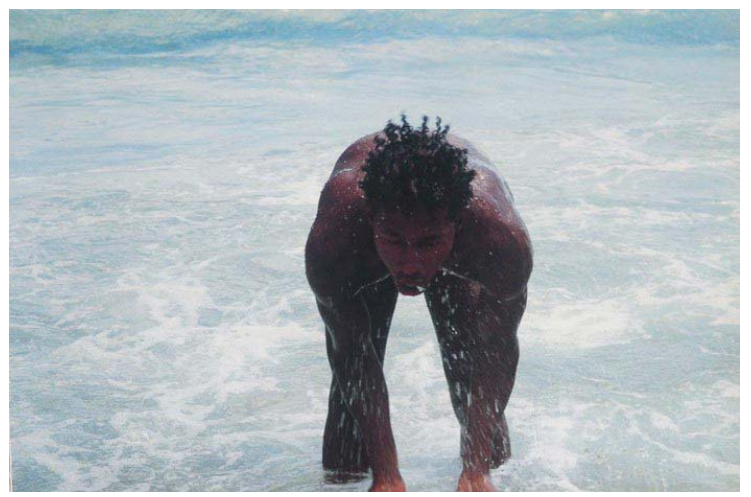

Fonte: Cravo Neto, 2000.

Além dessa, outras fotografias similares usadas no livro remetem igualmente a esse mito da criação dos orixás (Figura 3). São imagens de pessoas registradas em diferentes poses e situações aparentemente corriqueiras do seu cotidiano de lazer em alguma praia de Salvador. No livro, porém, todos esses personagens se passam por divindades. Em uma delas, Exu observaria a sua mãe, lemanjá, boiando desfalecida nas águas do mar. Em outra, é o orixá que, deitado na areia e semicoberto pela água, parece inconsciente do seu nascimento. Há ainda uma fotografia de um homem negro no mar que recolhe uma corbelha florida em uma alusão à tradição das oferendas para lemanjá as quais, se por ela recusadas, voltam à praia para a decepção de seus devotos.
Figura 3 - Mario Cravo Neto. Fotografias do livro Laróyè
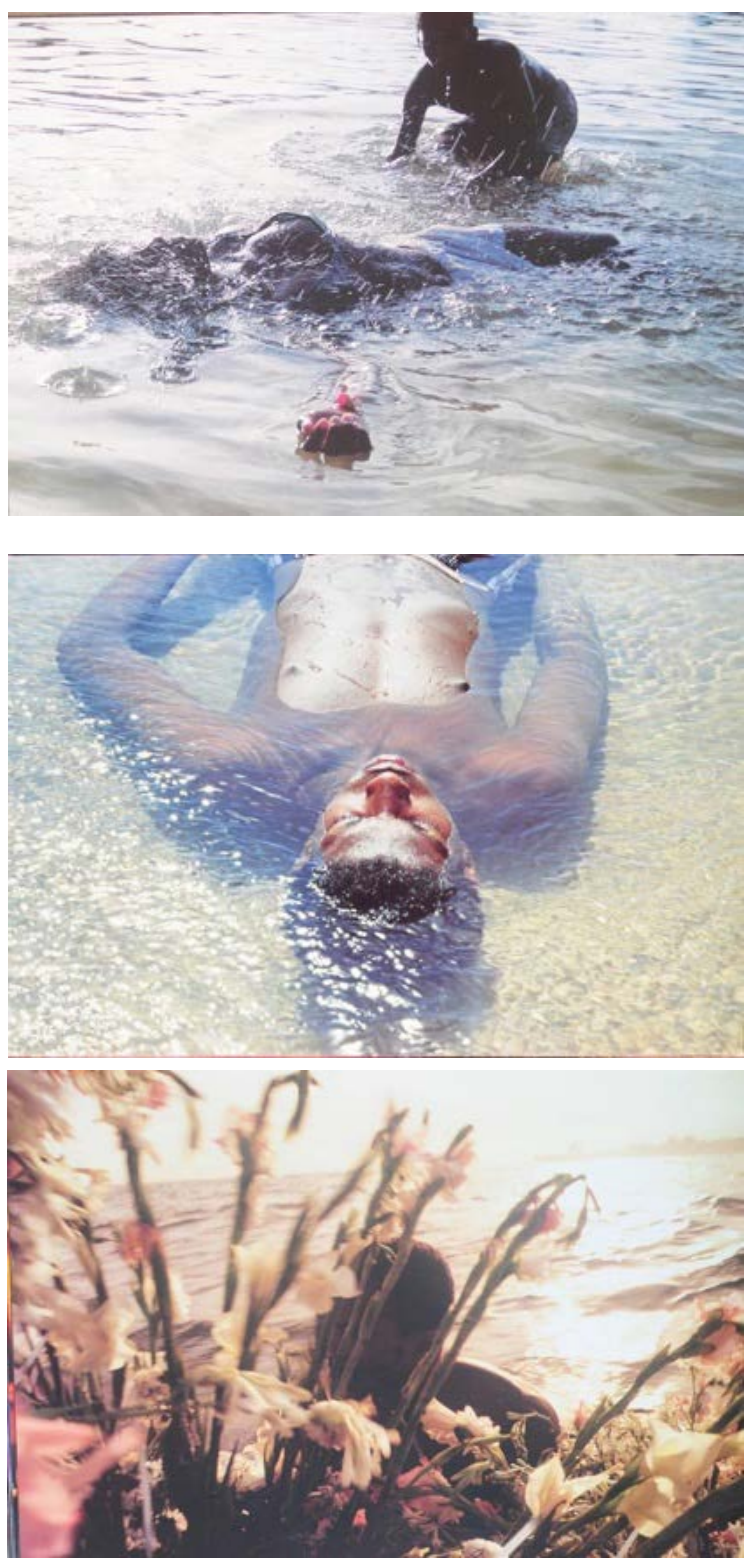

Fonte: Cravo Neto, 2000.

Em Laróyè, a presença de Exu pode ser notada tanto nas fotografias de homens, mulheres e crianças em contextos variados do seu cotidiano (nas águas do mar, no trabalho, nas ruas, nos mercados, nas igrejas, nas festas de largo e carnaval etc.) quanto nas imagens de animais e objetos ou ainda, de forma mais sutil, nas cores e nas sombras desses elementos. Todas elas dialogam com a simbologia e a mitologia sobre Exu e também com os rituais de culto aos orixás.

Dessa forma, para seguir com a análise de Laróyè, tal como fizemos com as imagens do "nascimento de Exu" e "morte de lemanjá" acima, é preciso que 
conheçamos algumas caracteristicas, papel e atributos desse orixá os quais são estudados por diversos autores como Carneiro (1977), Bastide (1978), Santos (1986), Verger (2002, 2012), Prandi (2001, 2005), entre outros que se dedicaram a pesquisar o candomblé no Brasil e a mitologia dos orixás, cujas histórias, orikis ${ }^{3}$ e cantigas narram a epopeia dos deuses iorubanos. Então, analisaremos parte das fotos do livro, mesclandoas com as informações sobre Exu pesquisadas por estes autores. Além disso, é preciso ressaltar que, como cada imagem parece estar ligada a uma cantiga ou a uma história mítica (ou parte dela), ou mesmo se refere a algum aspecto do ritual de culto aos orixás, Laróyè não apresenta uma narrativa linear que contaria uma história específica sobre Salvador, mas sugere a presença de Exu entre os seus habitantes. Por isso, a nossa análise não seguirá a ordem de apresentação das fotos no livro, que, apesar de não seguirem uma sequência cronológica, são organizadas em suas páginas no sentido de estabelecer relações entre a realidade da cidade e a pluralidade de histórias míticas que cercam este orixá.

Os mitos iorubanos são histórias que contam as aventuras dos orixás. Seguindo a tradição africana da oralidade, foram contados e recontados ao longo do tempo, trazendo por meio de metáforas os relatos sobre a vida e os feitos de cada um dos deuses. De acordo com Prandi (2001), na mitologia iorubá, assim como nos cultos do candomblé, Exu é apresentado como o deus mensageiro e possui um papel importante no panteão dos orixás. Um dos mitos conta que Exu foi aconselhado a coletar todas as histórias vividas pelos seres humanos, pelas divindades, bem como pelos animais e demais seres que dividem a Terra com os homens. Todas essas narrativas a respeito do cotidiano, além das providências tomadas e as oferendas dedicadas aos deuses para se chegar às soluções dos desafios enfrentados, foram reunidas por Exue totalizaram, ao final da missão do orixá mensageiro, 301 histórias que, de acordo com o sistema de enumeração dos antigos iorubás, representam um número incontável de histórias. Seu conteúdo equivaleria a todos os conhecimentos necessários para o desvelamento dos mistérios sobre a origem e o governo do mundo e da natureza, e também sobre o destino dos homens e os seus caminhos em suas lutas cotidianas.

O mito conta ainda que todo esse saber foi dado a um adivinho de nome Orunmilá, também conhecido como Ifá, que o transmitiu aos seus seguidores, os chamados babalaôs (os sacerdotes do oráculo de lfá ou os pais do segredo), que, no Brasil, correspondem aos atuais pais e mães de santo (babalorixás e ialorixás). Assim, os babalaôs aprendem essas histórias primordiais contendo os fatos do passado os quais se repetem a cada dia na vida dos homens, o que significa que para os iorubás antigos "nada é novidade, tudo o que acontece já teria acontecido antes. Identificar no passado mítico o acontecimento que ocorre no presente é a chave da decifração oracular" (PRANDI, 2001, p. 18). Nesse sentido, a tarefa do babalaô é saber em qual mito ou parte do mito se encontra no relato do passado a história do seu consulente do momento atual. "Ele acredita que as soluções estão lá e então joga os dezesseis búzios, ou outro instrumento de adivinhação, que the indica qual é o od $u^{4} \mathrm{e}$, dentro deste, qual é o mito que procura" (PRANDI, 2001, p. 18). E é nesse contexto que o papel de Exu foi definido, já que ele é o mensageiro responsável não apenas pela comunicação entre os babalaôs (a quem lhes ensinou a arte da adivinhação) e Orunmilá (o deus do oráculo), mas também pelo transporte das oferendas (ebós) 5 aos orixás, estabelecendo, então, o elo entre o mundo dos deuses (orun) e o mundo dos homens (ayê).

Em Mitologia dos Orixás (2001), Reginaldo Prandi apresenta uma compilação dessas 301 histórias míticas reunidas por Exu com os poemas oraculares que, por meio de figuras de linguagem, dão-nos uma ampla visão da religião dos orixás e ajudamnos a repensar as imagens do orixá mensageiro nos dias atuais. Afinal, acredita-se que com essas

\footnotetext{
Os orikis são versos e poemas entoados aos orixás que exaltam as suas virtudes, os grandes feitos e as suas qualidades. Preestabelecidos entre o povo iorubá, eles são os louvores usados durante os rituais para evocar os deuses iorubanos (VERGER, 2002).

4 Odu são signos do oráculo iorubano formado de mitos que dão indicações sobre a origem e o destino do consulente (PRANDI, 2001, p. 567).

5 Ebó é o sacrifício de animais para os orixás e também outras oferendas com objetos e alimentos a eles oferecidos.
} 
histórias poder-se-iam desvendar os mistérios, os atributos dos orixás e os diferentes sentidos das ações praticadas pelos homens no cotidiano dos terreiros (e também fora dele, como o faz Cravo Neto), oferecendo explicações para o uso de determinados objetos, cânticos, movimentos, vestimentas.

Quanto a Exu, Prandi (2001, p. 20-21) afirma ser ele um orixá "sempre presente, pois o culto de cada um dos demais orixás depende de seu papel de mensageiro". Nas festas de culto aos orixás (xirês), o despacho de Exu (padê) ${ }^{6}$ sempre acontece em primeiro lugar, antes mesmo do início dessas cerimônias. Segundo Verger (2002, p. 79), Exu é sempre o primeiro a ser chamado, saudado, cumprimentado e depois despachado com um duplo objetivo: "convocar os outros deuses para a festa e, ao mesmo tempo, afastá-lo para que não perturbe a boa ordem da cerimônia com um dos seus golpes de mau gosto". Além de serem realizadas antes dos cultos, estas oferendas também são feitas nas praias, matas e nas ruas das cidades, onde os devotos do orixá invocam os seus poderes, a fim de obterem algum tipo de benefício. Desse modo, nas fotografias abaixo (Figura 4), podemos constatar a influência das crenças africanas no papel de mensageiro de Exu sobre os habitantes de Salvador.

Figura 4 - Mario Cravo Neto. Fotografias do livro Laróyè

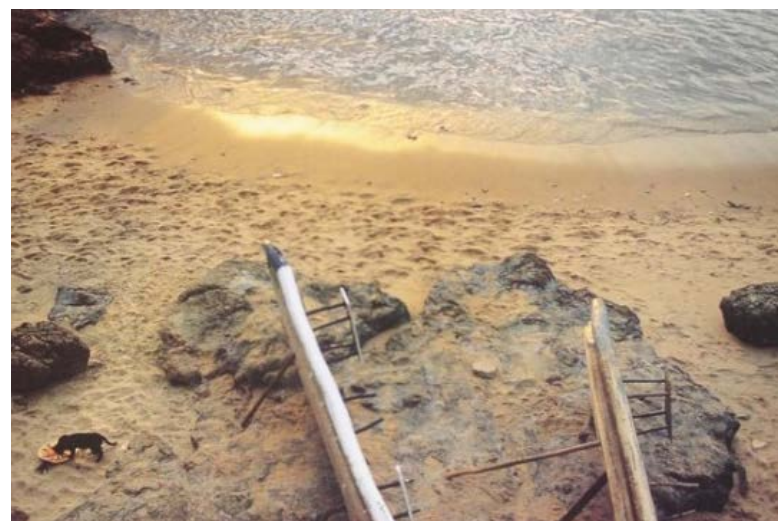

Fonte: Cravo Neto, 2000.

Na imagem à esquerda, observamos a cena de um amanhecer em uma das praias da cidade, onde um gato come os alimentos de uma oferenda feita, provavelmente, na noite anterior. Nela, a presença de Exu pode ser "observada", pois, como já sabemos, ele é o responsável pelo transporte das oferendas aos orixás. É também por meio dela que Exu se manifesta, intercedendo junto aos deuses em nome daquele que os invocou. Já na fotografia à direita, um homem é retratado em contraluz e ainda sob uma marquise a qual impede que os raios do sol o iluminem. Nessas condições, em silhueta e nessa pose, ele personificaria Exu. Segundo a mitologia dos

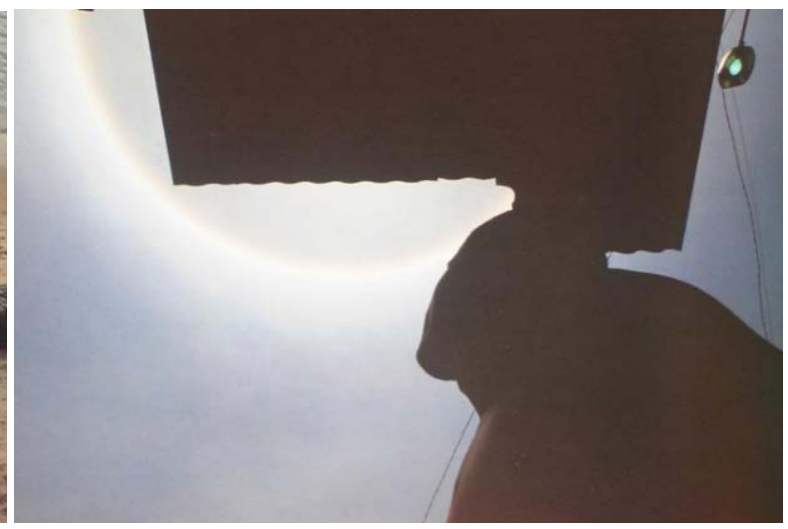

orixás, Exu, além de companheiro oculto dos homens, é o mensageiro entre estes e os deuses e, na imagem, o personagem de identidade não revelada, oculta, olha da terra (ayê) para o céu (orun) como se estivesse estabelecendo comunicação entre os dois planos.

Além de sua relevância como mensageiro, Prandi destaca também a sua importância no que toca às transformações no mundo material dos humanos, salientando que, sem a participação de Exu, chamado também de Exu-Elegbará, ou mesmo Legba entre os povos fon do Benin (ex-Daomé), "não há movimento, mudança ou reprodução, nem trocas mercantis, nem

\footnotetext{
- O padê é uma oferenda dedicada especialmente a Exu e significa reunião, momento em que se estabelece, por meio desse orixá, a comunicação entre os deuses e os iniciados do candomblé. O padê também é interpretado como o despacho de Exu no sentido de agradá-lo e, posteriormente, mandá-lo embora, para que o culto aos orixás siga sem problemas. Afinal, Exu pode fazer o mal e o bem, indiferentemente, dependendo da vontade do invocante (CARNEIRO, 1977, p. 59 e 138; BASTIDE, 1978).
} 
fecundação biológica" (2001, p. 21). Entretanto, o pesquisador destaca que, nos escritos dos viajantes, missionários e outros observadores os quais estiveram em território fon ou iorubá entre os séculos XVIII eXIX, todos eles de cultura cristã, este orixá foi "grosseiramente identificado com o diabo e ele carrega esse fardo até os dias de hoje" (PRANDI, 2001, p. 21)

Aesse respeito, Pierre Verger (2012, p. 119) explica que, além de ser o mensageiro dos outros orixás, bem como o guardião dos templos, das casas e das cidades, Exu "tem um caráter suscetivel, violento, irascivel, astucioso, grosseiro, vaidoso, indecente", o que chocou os primeiros missionários que "assimilaram-no ao Diabo e fizeram dele o símbolo de tudo o que é maldade, perversidade, abjeção e ódio, em oposição à bondade, pureza, elevação e amor a Deus" (2012, p. 119).

Em seu livro Nota sobre o culto aos orixás e voduns (2012), Verger cita relatos preconceituosos desses viajantes que, ao falarem de Exu, mostraram-se impressionados pelo aspecto erótico externado em suas representações, classificando-o como uma entidade sexualizada e demoníaca. Aos olhos dos ocidentais acostumados com a arte medieval renascentista, com esculturas e pinturas de santos assexuados cobertos com véus e rodeados de anjos, as estátuas de Exu, além de serem esteticamente muito diferentes das dos santos católicos e não estarem em templos, mas próximo às matas, nas encruzilhadas ou debaixo de simples choupanas cobertas de palha, ainda apresentavam um aspecto fálico muito acentuado (Figura 5). Eram efigies de Exu modeladas pelos iorubás na forma humana, com olhos, nariz e boca assinalados com búzios, ou de seu equivalente, Legba, representado por um montículo de terra em forma de homem acocorado, ornado com "um falo de tamanho respeitável", detalhe que escandalizou esses viajantes (VERGER, 2012, p. 127).
Figura 5 - Pierre Verger. Legba, guardião das casas em Abomé, República do Benin

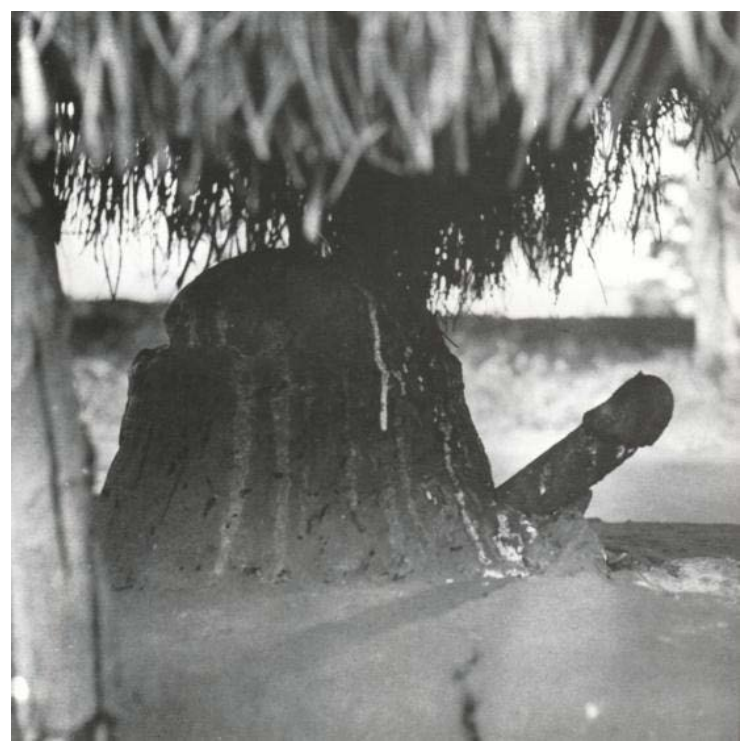

Fonte: Verger, 2012, p. 128.

Estas efigies com grande falo fizeram com que missionários e viajantes tomassem, confusa e arbitrariamente, Exu como o deus-fálico ou o deus da fornicação, cujo detalhe supostamente pecaminoso do órgão sexual o associava a Satanás. Porém, esta associação é, na visão do médico e pioneiro dos estudos afro-brasileiros, Nina Rodrigues (1935 apud VERGER, 2012, p. 138), "apenas um produto de uma influência de um ensino catholico".

Apesar de ter sido associado, erroneamente, ao diabo, é preciso lembrar que a figura de Exu é marcada por aspectos múltiplos e contraditórios, o que torna dificil defini-lo coerentemente. Segundo Verger (2002, 2012), Exu possui qualidades e defeitos; ele não é completamente bom, nem completamente mau. O seu caráter ambivalente o faz realizar ora boas, ora más ações - ambivalência semelhante à dos homens, caracterizando Exu como o mais humano dos orixás. Por um lado, ele é brincalhão, gosta de pregar peças de mau gosto, provocar acidentes e calamidades públicas e privadas, desencadear brigas, mal-entendidos e é considerado o companheiro oculto das pessoas, levando-as a fazer coisas insensatas e atiçando os seus instintos. Ademais, se as pessoas se esquecerem de lhe oferecer sacrificos e oferendas, Exu pode 
provocar catástrofes em suas vidas e, por isso, a ele são comumente oferecidos bodes, galos (de preferência pretos) e pratos cozidos em azeite de dendê. Por outro lado, "Exu possui o seu lado bom e, se ele é tratado com consideração, reage favoravelmente, mostrando-se serviçal e prestativo" (VERGER, 2002, p. 76). Assim, Exu é respeitado e reverenciado na África e muitas pessoas se orgulham ao usar o seu nome por considerarem-no também uma entidade dinâmica, esperta e jovial.

É preciso ressaltar ainda que Exu é ao mesmo tempo múltiplo e uno. Diz-se na Bahia que existem 21, segundo uns, e apenas sete do orixá, segundo outros, tendo eles nomes e apelidos, às vezes, oriundos das letras dos cânticos (VERGER, 2002, p. 79).7 Enquanto alguns podem ser ruins, outros são, ao contrário, muito bons. Diante desse contexto de mitos, representações e relatos com aspectos contraditórios sobre Exu, era previsível que novos pesquisadores, como Verger, contestassem as primeiras impressões relatadas nos séculos XVIII e XIX. Assim, ao contrário dos viajantes e missionários do passado que viram no grande falo o caráter demoníaco de Exu, estes novos pesquisadores atribuiram a esse aspecto das representações do orixá o seu poder de fecundação. Para alguns, sem Exu não haveria vida na Terra. Prandi (2005), por exemplo, argumenta que o falo acentuado nas representações de Exu se deve ao fato de o orixá ser o patrono da cópula, aquele que gera filhos e garante a continuidade do homem, embora reconheça que este aspecto tenha provocado a construção preconceituosa e estereotipada do deus libidinoso, lascivo e carnal. E Juana Elbein dos Santos (1986, p. 131.), por sua vez, aprofunda-se na questão e acrescenta que a existência dos seres (e das coisas) depende da presença desse orixá em seus corpos, sejam masculinos ou femininos.

Nesse contexto, que define Exu como um deus cujo falo representa positivamente o seu poder de fecundação - e não negativamente o seu suposto caráter indecente e pecaminoso pelo qual ele foi identificado ao diabo - Mario Cravo Neto vai buscar principalmente nos corpos dos seus personagens e em outros objetos este que talvez seja o principal símbolo do orixá. E ele o encontra nos mais distintos locais e de forma ora mais ora menos explícita.

Figura 6 - Mario Cravo Neto. Sem título, do livro Laróyè

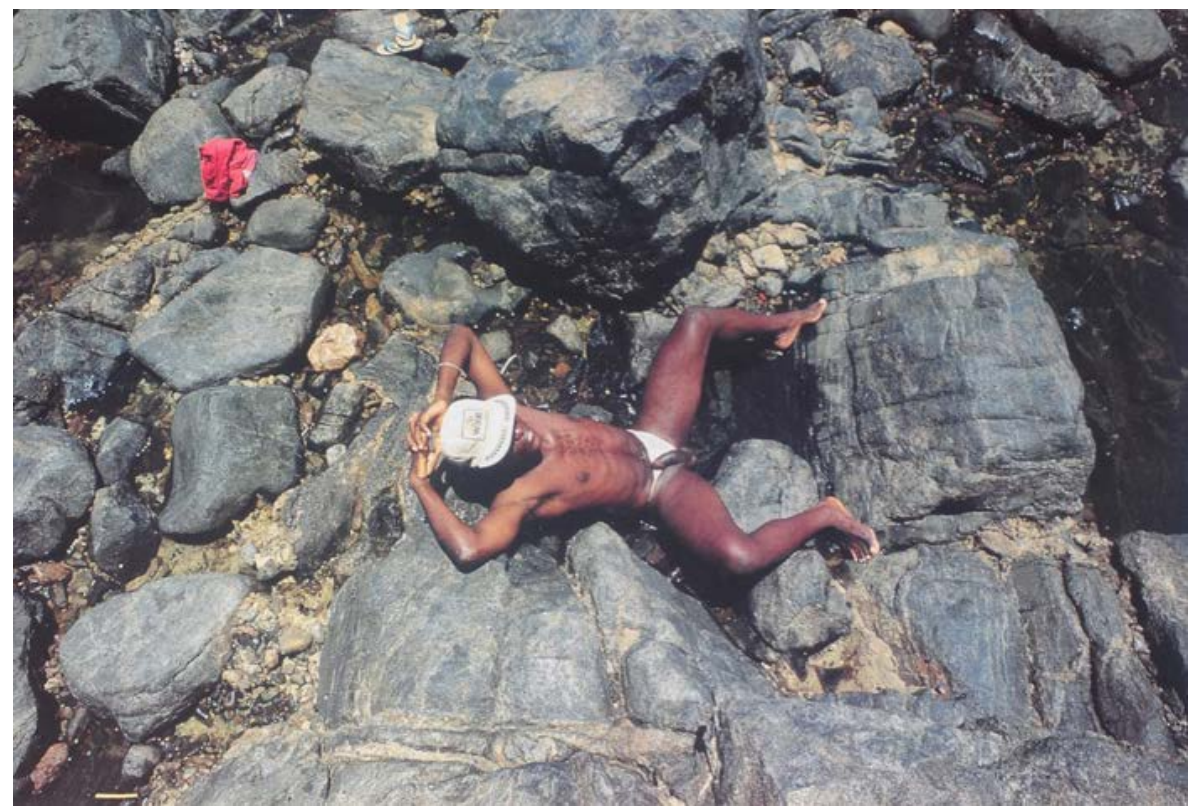

Fonte: Cravo Neto, 2000.

\footnotetext{
7 Verger (2002, p. 79) lista alguns, como Exu-Elegbá ou Exu-Elegbará e seus possiveis derivados: Exu-Bará ou Exu-lbará, Exu-Alaketo Exu-Laalu, Exu-Jelu, Exu-Akessan, Exu-Loná, Exu-Agbô, Exu-Laróyè, Exu-Inan, Exu-Odara, Exu-Tiriri.
} 
A imagem acima (Figura 6), por exemplo, apresenta um homem negro que, deitado sobre as pedras, toma tranquilamente o seu banho de sol. O ambiente parece ser pouco frequentado por banhistas a ponto de ele sentir-se à vontade para deixar o seu pênis à vista enquanto se bronzeia próximo ao mar. Trata-se, obviamente, de um flagrante no qual o homem foi captado não apenas em um momento íntimo, como também a partir de um ângulo em plongé apropriadamente escolhido pelo fotógrafo que, ao se posicionar em um local superior ao do seu personagem, pôde destacar elementos imprescindiveis para a sua identificação com Exu. Embora a abordagem ágil e sorrateira de Cravo Neto se assemelhe aos comuns e valorizados "flagrantes" da prática fotojornalística, o que era importante, dessa vez, não era o "roubo" de uma cena inusitada nem a busca pela representação da espontaneidade e identidade do personagem, mas somente aquilo que ele expôs e que, em Laróyè. reporta-nos ao orixá: o seu pênis, que se destaca na cena, e, ao seu lado, uma camiseta vermelha, cor a qual representa Exu.

Ainda sobre o aspecto fálico de Exu, Verger (2012, p. 131), apresenta dois orikis os quais são entoados ao orixá, exaltando as suas virtudes no que diz respeito ao seu poder de fecundação. No primeiro deles, "Fotifo que mostra seus testículos terá filhos que mostrarão seus testículos" percebemos uma forma de transferência de tal poder do orixá entre os membros familiares ao longo das gerações. Já o outro, com o verso "Esu, que os filhos não sejam raros em minha vida", reforça, por sua vez, o conceito do falo como símbolo de sua importância para a multiplicação dos seres na terra. Assim, seguindo com a associação das narrativas miticas e dos orikis com as imagens de Laróyè, Cravo Neto fotografa uma familia dormindo em uma rua de Salvador (Figura 7). A partir dessa imagem, podemos perceber que os versos dos orikis citados acima se relacionam diretamente com os elementos os quais a compõe. Primeiramente, há nela duas das crianças que se destacam pelo aspecto fálico: enquanto o pênis ereto de uma delas estica o seu calção, o seu provável irmão, dormindo nu ao seu lado, exibe também o seu pênis e testículos, como entoado pelo oriki. Além disso, três filhos nos parecem compor uma família numerosa; definitivamente, eles não são raros na vida de sua mãe presente no canto direito da imagem.

Figura 7 - Mario Cravo Neto. Sem título, do livro Laróyè

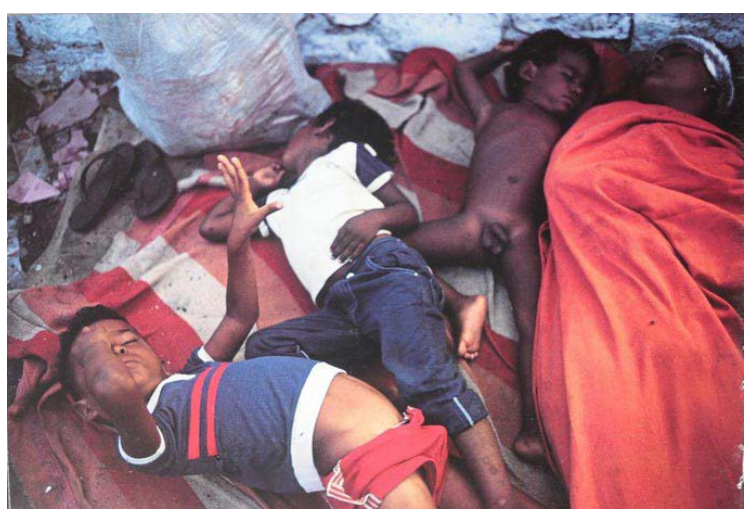

Fonte: Cravo Neto, 2000

Como já destacamos, o caráter fálico de Exu não está ligado ao amor carnal, ao sexo em si, mas sim ao seu poder de fecundação. Porém, além disso, cabe aqui ressaltarmos que alguns pesquisadores notam também que o falo acentuado nas representações desse orixá simboliza o poder de transformação e contestação da moral e dos costumes estabelecidos na sociedade. Nesse sentido, enquanto Verger (2002, p. 78, grifo nosso) esclarece que o falo ereto "nada mais é do que a afirmação do seu caráter truculento, atrevido e sem vergonha e de seu desejo de chocar o decoro", Sodré, em linha similar de raciocínio, aponta Exu como o "dono do corpo" e também parte de um ambiente. onde a sua razão de existir é senão a de destruir, reinventar papéis, estabelecer o caos, para criar novas filosofias do pensamento (MUNIZ, 1979 apud MENDONÇA, 2008, p. 60).

A partir dessa perspectiva, é possivel compreendermos a presença em Laróyè de uma série de fotografias produzidas durante o carnaval de Salvador (Figura 8). Nas festas de carnaval, é comum as mulheres se vestirem de homens, os homens de mulheres, as classes sociais se misturarem e os tabus de contato e de mistura que sustentam uma certa ordem social serem quebrados (BASTIDE, 
1978). E assim o faz Exu, quando ele exerce o seu poder de transformação e contestação da moral destacado pelos pesquisadores.

Figura 8 - Mario Cravo Neto. Fotografias do livro Laróyè
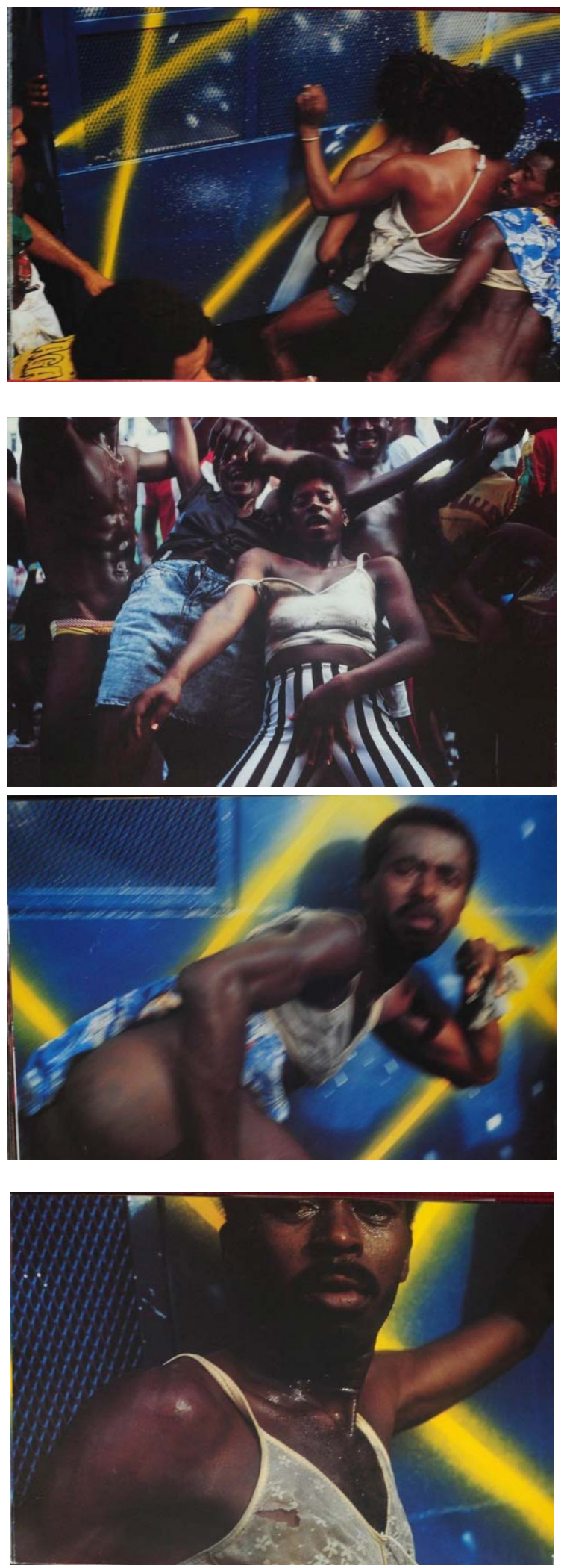

Fonte: Cravo Neto, 2000.
As imagens da série acima apresentam homens e mulheres em estado de êxtase que foge ao padrão do comportamento social durante os dias regulares do ano. Em uma delas, uma mulher se encontra prazerosamente espremida entre dois homens os quais, juntos e encostados em um trio elétrico, dançam e se deliciam em um momento de deleite mútuo que escandalizaria facilmente o olhar casto do ser puritano. O mesmo acontece nas outras três fotos desse grupo, seja na de uma mulher que, ao rebolar em meio à multidão suada, flexiona as suas pernas e estende a sua mão na direção de seu sexo, exibindo espontânea e eroticamente o seu passo de dança para as lentes do fotógrafo, seja na dupla de retratos de um mesmo homem que, portando vestido e usando maquiagem, traveste-se de mulher para, como Exu, chocar o decoro e reinventar novos papéis.

A maioria das fotografias dessa série do carnaval (e também do livro como um todo) são produzidas em planos médios. Assim, por um lado, com esses enquadramentos mais fechados Cravo Neto destaca aspectos dos corpos nus ou seminus dos seus personagens para, a partir deles e de suas atitudes transgressoras, remeter à figura de Exu e aos seus poderes que atuariam sobre as pessoas e o ambiente. Contudo, por outro lado, ao fragmentar tais corpos com esta intenção conceitual e poética, essa escolha formal de Cravo Neto, inevitavelmente, descontextualizaos da realidade de Salvador que os rodeia e, em uma perspectiva tradicional e, ao mesmo tempo, reducionista, retiraria Laróyè do campo da documentação por se tratar, então, de um trabalho exclusivamente conceitual e de interpretação pessoal do universo mítico dos orixás.

Em sua pesquisa de doutorado que discute e analisa a imagem fotográfica no espaço mítico e ritual do candomblé, Denise Camargo (2010, p. 99) observa corretamente que, em Laróyè, Mario Cravo Neto, apesar de não fazer referências diretas à prática religiosa, "constrói, imageticamente a figura de Exu" mediante registros do homem baiano integrado às manifestações populares e religiosas. Entretanto, após destacar um trecho da fala do fotógrafo o qual explica que as suas 
imagens "foram se agrupando em uma mesma temática: o corpo, a sexualidade, a sensualidade", a pesquisadora é taxativa ao definir Laróyè: "não é documentação e, sim, interpretação da mítica baiana". Embora concordemos com Camargo quando ela nota com razão que Cravo Neto "reconhece os orixás entre nós", não vemos oposição entre documentação fotográfica e interpretação dos aspectos míticos presentes na realidade social da Bahia. Ao colocá-las em lados opostos, a pesquisadora parece entender a documentação como um trabalho necessariamente de produção de registros objetivos do real, de discursos visuais de caráter realista e factual nos quais não se permite uma abordagem interpretativa e, portanto, subjetiva dos temas - nesse caso da mítica baiana. Em suma, quaisquer documentações independentemente de suas particularidades - parecem ser entendidas como "fotografia documental" e, consequentemente, como um gênero de imagens consideradas, em geral (e não apenas por Camargo), como reproduções do mundo exterior; ou seja, imagens pouca elaboradas já que não interpretativas.

Sobre o status de Laróyè e mais especificamente da série de fotografias do carnaval, Mario Cravo Neto faz um importante comentário que nos permite refletir sobre o seu trabalho no contexto da afirmação de Camargo e do presente estudo, o qual aborda os termos documentação e fotografia documental, bem como o conceito de documento, cuja etimologia e noção original está ligada à sua função didática (docere, ensino) - portanto diferente do seu sentido moderno de testemunho e prova. ${ }^{8}$ Em entrevista a Euriclésio Barreto Sodré (2006, p. 127-128), Cravo Neto comenta que na narrativa do livro há duas imagens que "destoam da plástica do conjunto, da continuidade apresentada", embora ele tenha decidido "por bem colocar para mostrar o ambiente em que isso foi fotografado". Trata-se de duas fotografias capturadas de cima de um trio elétrico (Figura 9) que, diferentemente daquelas que fragmentam a realidade ao serem produzidas muito próximas às pessoas em êxtase dançando nas ruas lá embaixo, contextualizam a atmosfera do local e servem, segundo o próprio o fotógrafo, como "elemento didático". Portanto, é interessante destacar a percepção de Cravo Neto no que toca à dupla carga (estética e informativa) da fotografia enquanto meio de expressão poética e comunicação, e como essa percepção the influenciou na edição de Laróyè que, na sua opinião, "seria mais homogêneo sem estas duas fotos. Eu digo isso sinceramente, mas eu precisava de um elemento didático pra dizer que estas fotos foram feitas nessa loucura, porque o pessoal vai no carnaval, mas não vai lá dentro" (CRAVO NETO, 2005 apud SODRÉ, 2006, p. 127-128).

Figura 9 - Mario Cravo Neto. Fotografias do livro Laróyè
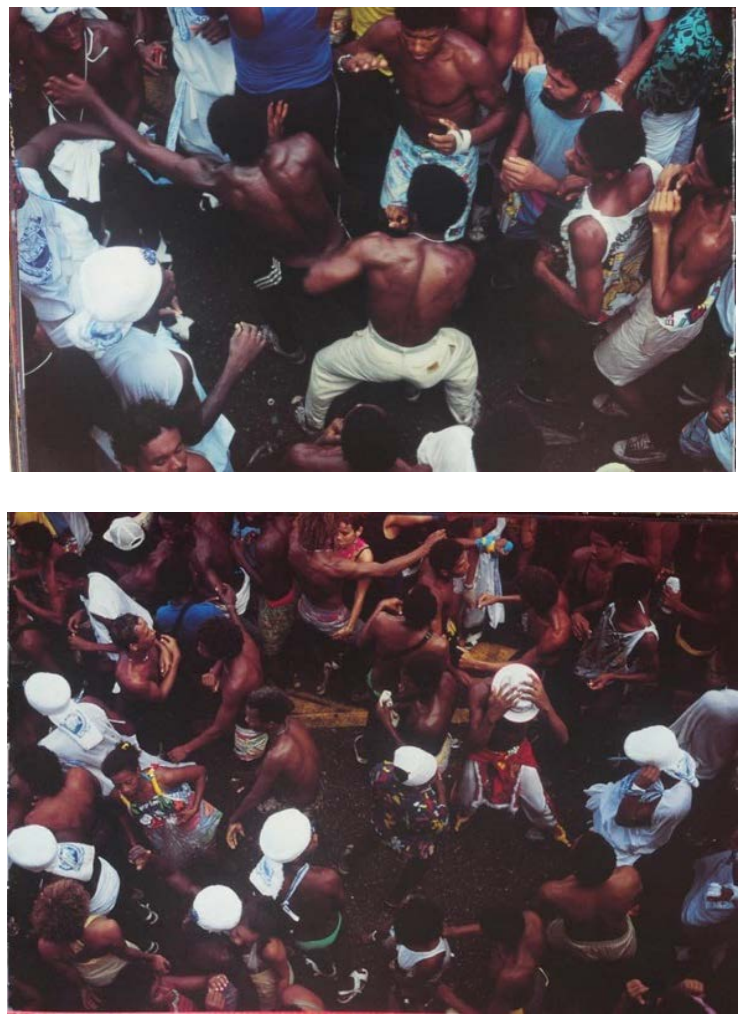

Fonte: Cravo Neto, 2000.

\footnotetext{
8 Em seu livro História e Memória (1996), o historiador Jacques Le Goff explica que "o termo latino documentum, derivado de docere 'ensinar', evoluiu para o significado de 'prova' e é amplamente usado no vocabulário legislativo. É no século XVII que se difunde, na linguagem jurídica francesa, a expressão titres et documents e o sentido moderno de testemunho histórico data apenas do início do século XIX. O significado de 'papel justificativo', especialmente no domínio policial, na língua italiana, por exemplo, demonstra a origem e a evolução do termo" (LE GOFF, 1996, p. 536).
} 
De fato, essas duas imagens apresentam mais amplamente a realidade do carnaval e dos personagens sem, contudo, escapar ao tema-conceito do livro. Afinal, elas mostram a paradoxal atmosfera de alegria e tensão que oscila entre os foliões na "pipoca" desses festejos de rua de Salvador e, ao mesmo tempo, remetem, como todas as fotos do livro, à figura de Exu, que fundamenta a proposta conceitual de Laróyè. Então, é possivel associá-las, por exemplo, aos versos de dois orikis colhidos por Verger (2012) que descrevem o temperamento ora violento ora apaziguador do orixá. A imagem à esquerda, em que vemos ao centro um homem com a guarda armada em posição de luta, pode ser entendida a partir da leitura de parte de um oriki cujo verso afirma: "ele procura briga com alguém e encontra o que fazer". Já na imagem à direita, provavelmente registrada no mesmo local, mas em um instante anterior ou posterior ao momento da foto ao lado, o homem brigão já não se encontra e o clima de festa volta a reinar graças a "Ėsù, que empurra para fora as pessoas que querem brigar" (VERGER, 2012, p.143).

Diante desse contexto, percebemos que, além de as fotos de Laróyè documentarem de maneira singular a realidade de Salvador, elas também revelam a interpretação pessoal do Cravo Neto sobre o carnaval soteropolitano, entre outros temas do cotidiano a partir dos quais o fotógrafo, como observou Camargo, "constrói a figura de Exu". E ainda sobre este dupla função do seu trabalho de documentação e interpretação, é preciso destacar que as imagens Laróyè atuam não apenas para interpretar a mítica de Exu como também para resgatar a memória da capital baiana do final do século $X X$, já que a poética do livro aborda a cidade tanto em seus aspectos míticos, envolvendo Exu e o sincretismo religioso da capital mais miscigenada do Brasil, quanto em suas questões históricas e culturais, ao eternizar cenários que se modificaram ou não existem mais.

Em sintese, além de evocar um deus do candomblé e nos fazer vê-lo personificado no povo baiano, Laróyè é uma obra-memória desse mesmo povo e de como ele se organizava em um passado recente. Ainda que Cravo Neto não se feche exclusivamente no registro dos fenômenos sociais visiveis da realidade da cidade, ele parte dela $e$ dos seus aspectos míticos para sugerir a presença de Exu entre os seus habitantes. Estamos, assim, diante de um trabalho de documentação que, ao não se resumir na produção de um discurso visual realista, ao não se fechar nos aspectos factuais de determinado espaço-tempo da capital baiana, expande as fronteiras do documentário fotográfico, ao tratar da complexidade abstrata de uma divindade invisivel, mas perceptivel pelo contexto poético de Laróyè. Dessa forma, o seu autor, ao mesmo tempo em que se preocupa com um "elemento didático" para conferir "um pouco de lógica" à sequência das imagens do livro, não deixa, contudo, de expressar poeticamente "um pouco do aspecto místico" da sua personalidade artística; misticismo este que é também inerente à filosofia e mitologia africanas e ao universo do orixá Exu. Sobre esta dupla abordagem, o fotógrafo explica que

[...] como artista eu tenho um pouco de lógica e um pouco do aspecto místico que me permite um certo tipo de trânsito, um certo tipo de dualidade sem querer estabelecer nenhuma lógica no sentido de que eu não quero estabelecer nenhuma equação matemática (CRAVO NETO, 2005 apud SODRÉ, 2006, p. 129, grifo nosso).

Nesse sentido, ao afirmar que o aspecto místico lhe permitiria "um certo tipo de trânsito", podemos comparar este trânsito em sua personalidade com a própria flexibilidade estatutária (ou mesmo indefinição) do seu trabalho entre o campo da documentação, no qual deveria supostamente haver "um pouco de lógica", e a produção artística, mais aberta ao "aspecto místico" no caso de Laróyè. Ainda que a sua atitude de perambular pelas ruas realizando crônicas visuais da cidade o aproxime da figura do repórter fotográfico ou da do documentarista, Cravo Neto, ao relacionar a realidade visivel no cotidiano do povo baiano com a mitologia dos orixás, acaba registrando os seus personagens dentro de uma atmosfera que pertence à ordem do sagrado, daí surgido o "aspecto místico" desse livro.

Em Laróyè, Cravo Neto não possui uma pauta definida, um assunto factual e concreto a apurar, 
nem busca revelar uma verdade absoluta sobre os seus personagens e sobre a religião dos orixás. Ademais, as imagens do livro, apesar de se conectarem por um conceito em comum (Exu), agrupam-se em séries distintas com temáticas mais abertas e abstratas e, juntas, não constituem exatamente um ensaio fotográfico com uma história especifica, o que destoa das narrativas tradicionais do fotojornalismo e do documentarismo.

Na produção de algumas imagens de Laróyè, há ainda um componente inovador no contexto da documentação fotográfica no Brasil, entre os anos 1970 e 1990, que não nos permite classificar Cravo Neto como um fotógrafo estrita e tradicionalmente documental: o assumido planejamento prévio das cenas, envolvendo a escolha do local, do modelo e da sua pose, adiciona ao livro, como veremos em seguida, um aspecto ficcional que demonstra a sua importante contribuição no processo de ruptura com a noção de documento fotográfico como prova do real e com o próprio conceito de "fotografia documental" enquanto gênero voltado à produção de imagens realistas. Consequentemente, Laróyè também contribui para a expansão das fronteiras as quais aprisionavam a documentação fotográfica dentro de tal gênero e que, histórica e tradicionalmente, não lhe permitiam ser considerada como uma forma de criação artística.

A fotografia que talvez mais destoe do conjunto de imagens apresentadas em Laróyè foi realizada dentro de uma igreja de Salvador (Figura 10). A sua singularidade se dá, primeiramente, pelo fato de ela mostrar um homem sem camisa dentro de um ambiente sagrado. Trata-se, então, de uma cena inusitada e sugere que o personagem seja a personificação de Exu, não apenas pela sua cor negra, mas, sobretudo, por sua atitude transgressora responsável por instaurar um clima de tensão ao postar-se de maneira irreverente diante de uma estátua católica: com uma das mãos na cabeça, o negro - de cabelo trançado e braços musculosos - encontra-se escorado sobre um banco da igreja de onde contempla tranquilamente a figura de um santo católico branco que, em situação, diriamos, oposta - não apenas pela sua cor, mas também pela expressão facial angustiante - mantém a sua cabeça erguida ao alto como se rogasse o perdão de Deus, enquanto realiza a sua penitência, como indicam o cordão em sua mão e o bracelete e o cinturão sangrando o seu corpo.

Figura 10 - Mario Cravo Neto. Sem título, do livro Laróyè

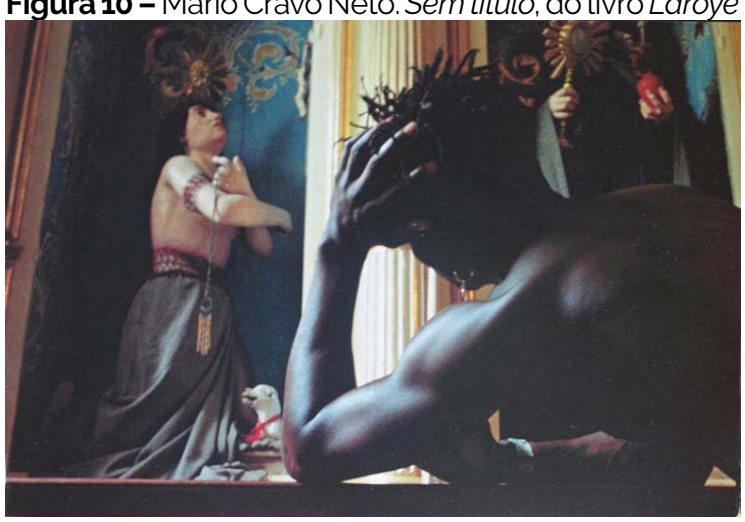

Fonte: Cravo Neto, 2000

Além disso, pela pose do homem negro e por sua seminudez em uma local como esse, podemos supor que a imagem tenha sido encenada, o que insere em Laróyè um componente ficcional o qual renovaria os padrões tradicionais da documentação fotográfica no Brasil. Embora não possamos afirmar que essa fotografia tenha sido posada, Cravo Neto, ao ser questionado sobre a existência em Laróyè de imagens previamente elaboradas com modelos, admite que nesse livro "muito poucas são assim" (CRAVO NETO, 2005 apud SODRÉ, 2006, p. 129).

Exu também é representado pelas cores preto e vermelho e as pessoas que procuram a sua proteção usam colares de contas nestas tonalidades. Santos (1976, p. 170-171) explica, contudo, que estas cores, bem como o branco, correspondem Exu não como matizes, mas por meio dos seus significados plenos: o preto seria o aspecto de Exu que regularia o processo oculto, indecifrável e secreto que acontece no seio da matéria gestadora, o branco seria a existência genérica, sem cuja matéria não haveria existência individualizada e, por fim, o vermelho constitui o fogo e possui diversos sentidos, sendo muito associado ao sangue que circula e dá vida; o vermelho genitor, sangue vermelho como poder de gestação veiculado pelo corrimento menstrual. Assim, é possivel identificar nas fotografias de Laróyè a predileção do seu autor pelas tonalidades que representam Exu, o que pode ser notado 
inclusive na página de guarda do livro, impressa toda em vermelho. O preto e o vermelho são cores presentes em muitas das imagens dessa obra. Em algumas, o vermelho predomina no grafismo pintado nas barracas das feiras e mercados e também na lona plástica de uma delas, sob a qual ainda vemos o preto nas ripas de madeira e na pele do personagem (Figura 11)

Figura 11 - Mario Cravo Neto. Sem título, do livro Laróyè
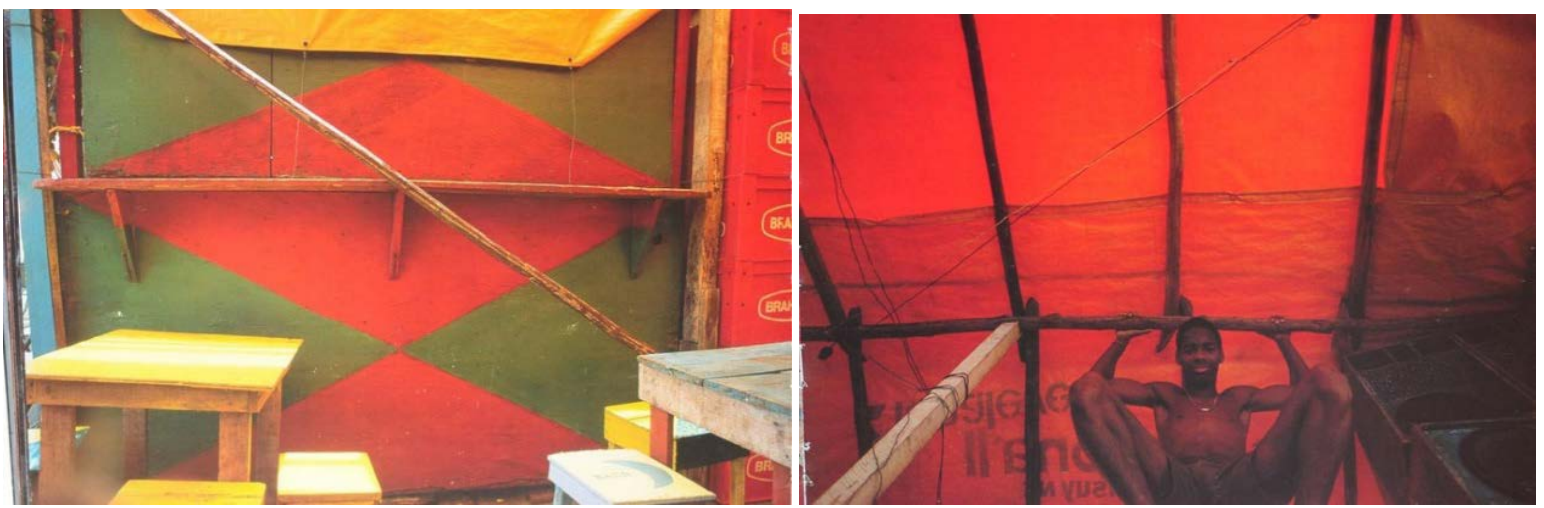

Fonte: Cravo Neto, 2000.

Outros poderes de Exu são simbolizados por meio de instrumentos e vestimentas que compõem algumas das várias imagens dessa divindade. 0 ogó, bastão ou porrete em formato fálico, símbolo do seu poder de criação, é um componente tão recorrente em suas representações quanto à faca. Exu, como já observamos, é conhecido por diversos nomes, sendo Obé Exu o "senhor da faca", aquele que maneja a faca que separa e auxilia o nascimento e propicia a morte. Este objeto aparece em algumas imagens de Laróyè e remete aos sacrifícios realizados antes do início do culto aos orixás, como forma de agradá-los, alimentá-los.

Sobre este importante momento do ritual de culto aos orixás, Carneiro (1977, p. 59) explica que uma festa de candomblé começa geralmente com os "sacrifícios de animais, galo, bode, pombo, etc., ao som de cânticos e em meio a danças sagradas". Assim, com base nesse indispensável ritual de matança em homenagem aos orixás e, principalmente, ao despacho de Exu para que ele não atrapalhe o bom andamento da festa, Cravo Neto insere nas páginas de Laróyè uma série de imagens de animais, vivos e mortos (Figura 12). Enquanto em uma das imagens abaixo observamos duas cabeças e outras parte de bodes sobre uma bancada de cerâmica, em outra, três galos se equilibram sobre uma gaiola repleta de pombos, incrementando assim a lista de bichos cujo sangue será oferecido aos orixás.

Figura 12 - Mario Cravo Neto. Fotografias do livro Laróyè
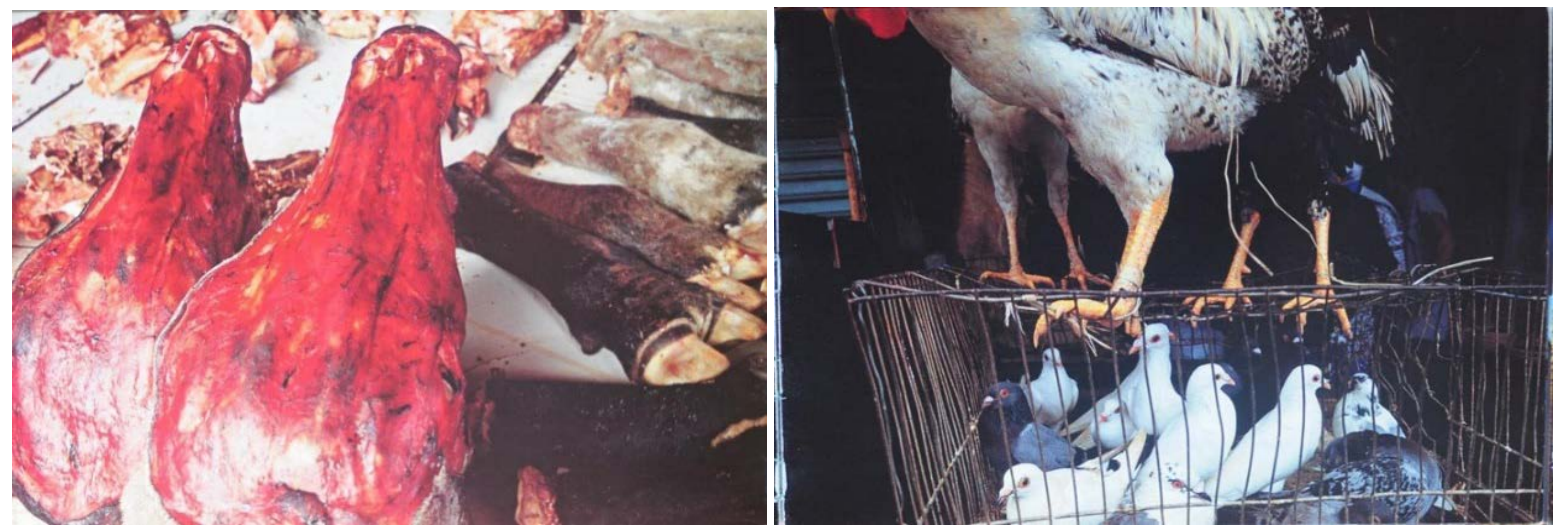

Fonte: Cravo Neto, 2000. 
Não apenas nessas, mas na maioria das fotografias de Laróyè, as referências aos rituais de culto aos orixás, bem como ao seu mundo mítico, dão-se de forma indireta e poética, ou seja, Mario Cravo Neto trabalha por meio de metáforas visuais, no sentido de permitir ao espectador chegar à sua própria interpretação das imagens e estabelecer a conexão dos seres e coisas nelas registradas com tais ritos e mitos. Esta estratégia de sugerir metaforicamente a figura de Exu persiste de diversas maneiras no livro como, por exemplo, em um simples registro de uma banca de feira (Figura 13).

Figura 13 - Mario Cravo Neto. Sem título, do livro Laróyè

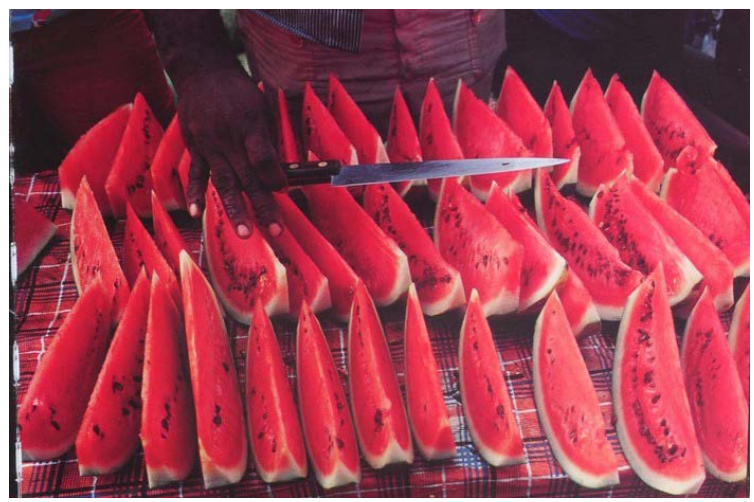

Fonte: Cravo Neto, 2000.

Ainda que apresente figurativamente os seus elementos constitutivos, a foto não se presta exatamente - pelos menos não em Laróyè - à representação dos aspectos físicos, materiais, das fatias de melancia e da parte do braço de um homem negro com uma faca na mão. Aqui é importante destacarmos que esta imagem foi primeiramente publicada em 1980, no livro seminal do autor intitulado Bahia, sob a legenda "Vendedor de melancia, Feira de São Joaquim, 1979". Nele, essa fotografia tinha como função a mera descrição de um produto à venda, evidenciando, assim, apenas um detalhe da realidade visivel dessa feira de Salvador. Entretanto, com base no conceito desenvolvido por Cravo Neto para Laróyè, uma saudação a Exu, essa mesma imagem é nele ressignificada. Dessa forma, se ela tiver uma função específica nessa obra, seria a de reificação do orixá, uma entidade imaterial, por meio de um de seus símbolos, esse sim material: a faca.

\section{Considerações finais}

No presente artigo, mostramos o trabalho de construção poética de Mario Cravo Neto. Ao transformar os corpos dos seus personagens e de animais, objetos, cores e até determinadas situações em metáforas que levam a "ver" o orixá Exu neles materializado, ele demonstrou que os possiveis sentidos das fotografias de Laróyè transcendem o significado primeiro dos referentes por elas registrado.

Exu, tal como todos os deuses e os mortos, pertence ao "terreno do enigma, do inatingivel", como pontua Canongia (2003, p. 12), e a sua presença no mundo material dos homens e, sobretudo, no espaço profano das ruas (ou seja, fora do ambiente sagrado dos terreiros) é quase imperceptível. Isso exigiu que Cravo Neto estivesse sintonizado com a mitologia, a ritualística e a simbologia do orixá para poder identificá-lo transfigurado nos seres e coisas em Salvador, onde as referências ao deus, mais do que em qualquer outra cidade brasileira, fazemse notar; porém, não facilmente e, claro, não a todos os seus habitantes e, sim, àqueles que, como o fotógrafo, foram iniciados no candomblé e se relacionam ou conhecem o universo dos orixás. Laróye nasceu, então, de um trabalho não exatamente de busca e registro do visivel - até mesmo porque os deuses não o são, ao menos para muitos de nós - mas, sim, de materialização (em fotografia) do imaterial por meio da identificação, seleção e agrupamento de referências visuais a Exu que indicassem a sua presença na capital baiana.

Há, portanto, uma questão importante no processo de elaboração de Laróyè, tanto na produção de suas fotos quanto na sua edição. Reunindo fotografias produzidas em um periodo de mais de 20 anos de documentação, esta obra não foi concebida de modo convencional em relação aos padrões do fotojornalismo nem ao modelo tradicional da chamada "fotografia documental". Ou seja, aquele tipo em que o 
fotógrafo define um tema, parte para o campo, fotografa durante um periodo mais curto ou mais longo de tempo, reúne uma quantidade de fotografias e as edita aos moldes de um ensaio para contar, geralmente, por meio de uma narrativa linear, uma história de uma época determinada e com personagens identificáveis. 0 que percebemos em Laróyè é que essa estreita relação de Exu com o seu autor ${ }^{9}$ mostra que. desde o início do processo de concepção do livro, Cravo Neto trabalhou menos como um produtor de imagens no sentido de documentar um tema específico do que como um editor o qual, com a sensibilidade e o saber privilegiados advindos das qualidades míticas dessa divindade, foi até o seu arquivo e recuperou certas imagens para evocá-la por meio de cenas, objetos, animais e atitudes de seus personagens.

Nesse sentido, Laróyè é o resultado de uma construção aparentemente deslocada das intenções iniciais do fotógrafo em seus primeiros dos 20 anos desse longo "trabalho de campo" que culminou em sua publicação. Além disso, as fotografias não constituem uma narrativa com uma história apenas sobre Salvador. Trata-se, mais precisamente, de conjuntos de imagens nos quais cada uma delas contém simbolos ou situações que remetem também a pelo menos uma história mítica (ou parte dela) sobre o orixá Exu, ou aos ritos do candomblé. Juntas, elas formam um mosaico imagético sobre a realidade da cidade e a complexa figura dessa e de outras divindades, não obrigando ao seu espectador, portanto, uma leitura sequencial deste livro.

Mais do que representar Exu trata-se de olhar para a cidade com o olhar com que ela educou o fotógrafo a ver, ou seja, assimilar uma cultura e uma maneira de ser. Isso torna o seu trabalho ainda mais pungente e perspicaz. Não é apenas o olhar de Cravo Neto que olha, o olhar do artista com o seu percurso prévio de envolvimento com as artes, mas o olhar da cidade que também o formou como fotógrafo.
Em suma, Cravo Neto uniu, de maneira inovadora, documentação e interpretação das realidades social e mitológica em Salvador mediante uma elaborada construção de metáforas visuais ambíguas que, partindo da simbologia de Exu, ressignificam situações banais do cotidiano da capital baiana. Ademais, algumas imagens de Laróyè são resultantes de procedimentos ficcionais e, embora colocam em xeque, de maneira mais evidente, o realismo fotográfico, este planejamento prévio das cenas ocorre muito pontualmente no livro, sendo principalmente as metáforas nas suas imagens (encenadas ou não) que não nos permitem classificá-lo com uma publicação estrita e tradicionalmente "documental". Portanto, são elas que ampliam a noção de documentação como trabalho de reprodução do mundo visivel ao tornar perceptivel - pela contextualização poética do sincretismo religioso da Bahia - uma divindade invisivel como Exu, entidade mítica importante e muito reverenciada no candomblé deste Estado brasileiro.

Ao utilizar variadas estratégias técnicas, estéticas e conceituais (movimento, silhueta, ressignificação simbólica, encenação, mistura de elementos barrocos do catolicismo com símbolos afro-brasileiros do candomblé etc.) para documentar a realidade social e mítica da Bahia, Cravo Neto mostra justamente o quão tênues, imprecisas e flexiveis são as fronteiras que insistiram e, por vezes, ainda insistem em separar a documentação fotográfica do campo da arte. Essas estratégias poéticas subvertem as noções de prova e testemunho da verdade atribuidas ao documento fotográfico; noções sobre as quais a chamada "fotografia documental" se baseou, associando-se mais tarde às práticas do fotojornalismo que predominaram com a ascensão dos meios de comunicação impressos, notadamente as revistas ilustradas, na primeira metade do século $X X$.

\footnotetext{
9 Em entrevista a Diógenes Moura, Cravo Neto afirmou que não foi ele quem escolheu Exu, mas o contrário, e que isso teria se dado quando o fotógrafo passeava "nas tantas encruzilhadas que a vida nos reserva" (CRAVO NETO apud MOURA, 2000, p. 80-81). Cravo Neto explicou ainda que "Exu gosta de mim, eu gosto dele. Quando digo que fui escolhido, quer dizer que sou a forma; ele, o conteúdo mítico, o centro do arquétipo, a minha relação com o numinoso".
} 


\section{Referências}

BASTIDE, Roger. O candomblé na Bahia: rito nagô. 2. ed. São Paulo: Nacional, 1978.

CAMARGO, Denise Conceição Ferraz de. Imagética do candomblé: uma criação no espaço mítico-ritual. 2010. Tese (Doutorado em Artes) - Universidade Estadual de Campinas, Campinas, 2010.

CANONGIA, Ligia. Texto de abertura. In: CRAVO NETO, Mario. Na terra sob meus pés. Rio de Janeiro: Centro Cultural Banco do Brasil, 2003. p. 9-15.

CARNEIRO, Edison. Candomblés da Bahia. 5. ed. Rio de Janeiro: Editora Civilização Brasileira, 1977.

CRAVO NETO, Mario. Bahia. Salvador: Raizes, 1980

CRAVO NETO, Mario. Laróyè. Salvador: Áries, 2000

DUBOIS, Phillipe. $\mathbf{O}$ ato fotográfico. Campinas: Papirus, 1994

FACHIN, Odilia. Fundamentos de metodologia. 3. ed. São Paulo: Saraiva, 2001

FONSECA, João José Saraiva da. Metodologia da pesquisa cientifica. Fortaleza: UEC, 2002. Apostila.

FLUSSER, Vilém. Filosofia da caixa preta: ensaios para uma futura filosofia da fotografia. Rio de Janeiro: Sinergia Relume Dumará, 2009.

FONTCUBERTA, Joan. El beso de Judas: Fotografia e Verdad. Barcelona Editorial Gustavo Gili, 2000.

HERKENHOFF, Paulo. A espessura da luz: fotografia brasileira contemporânea. São Paulo: Câmara Brasileira do Livro, 1994. (Confluência de Culturas, 46ª Feira do Livro de Frankfurt).

KOSSOY, Boris. Realidades e Ficções na trama fotográfica. Cotia: Atelier Editorial, 2002.

LEFFINGWELL, Edward. Prefácio. In: CRAVO NETO, Mario. Laróyè. Salvador: Áries, 2000. Livro não paginado.

LE GOFF, Jacques. Documento/Monumento. In: LE GOFF, Jaques. História e memória. Tradução Bernardo Leitão et al. 4. ed. Campinas: UNICAMP, 1996. p. 535-549.

MACHADO, Arlindo. A ilusão espetacular: introdução à fotografia. São Paulo: Brasiliense/Funarte, 1984. (Coleção Primeiros Vôos).

MENDONÇA, Adriana Aparecida. Laróyè: Exu na obra de Mario Cravo Neto. 2008. Dissertação (Mestrado em Cultura Visual) - Universidade Federal de Goiás, Goiânia, 2008

MOURA, Diógenes. Exu revelado. República, São Paulo, ano 4, n. 48 , out. 2000.

PRANDI, Reginaldo. Mitologia dos orixás. São Paulo: Companhia das Letras, 2001.

PRANDI, Reginaldo. Segredos guardados. Orixás na alma brasileira. São Paulo: Companhia das Letras, 2005.
PRODANOV, Cleber Cristiano; FREITAS, Ernani Cesar de. Metodologia do trabalho científico. 2. ed. Novo Hamburgo: Feevale, 2013.

SANTOS, Juana Elbein dos. Os Nàgô e a morte: Pàde. Àsèsè e o culto Égun na Bahia. Petrópolis: Vozes, 1986.

SODRÉ, Muniz. Samba: o dono do corpo. Rio de Janeiro: Codecri, 1979.

SODRÉ, Euriclésio Barreto. Laróyè: uma poética de Exu em Mario Cravo Neto. 2006. Dissertação (Mestrado em Artes Visuais) - Universidade da Bahia, 2006.

SOULAGES, François. Estética da fotografia: perda e permanência. São Paulo: Editora SENAC. São Paulo, 2010.

VERGER, Pierre. Orixás: deuses iorubas na África e no Novo Mundo. 6. ed. Salvador: Corrupio, 2002.

VERGER, Pierre. Nota sobre o culto aos orixás e voduns. São Paulo: EDUSP, 2012.

\section{Rafael Castanheira}

Doutor em Comunicação pela Universidade de Brasilia (UnB), Brasilia, DF, Brasil, com bolsa sanduiche na Université Paris 8 - Vincennes Saint-Denis. Mestre em Artes e Cultura Visual pela Universidade Federal de Goiás (UFG), com graduação em Comunicação Social - Jornalismo (2003) e especialização em Fotografia como Instrumento de Pesquisa nas Ciências Sociais pela Universidade Candido Mendes - RJ. Professor na Universidade Católica de Brasilia (UCB) Brasilia, DF, Brasil e desenvolve projetos pessoais em fotografia, como ensaios, pesquisas e curadorias.

\section{Endereço para correspondência}

Rafael Castanheira

Condomínio Quintas Bela Vista, conj. B, casa 6

Jardim Botânico, 71680604.

Brasilia, DF, Brasil 